\title{
Psychological contract breach and innovative work behaviour: Systematic literature review
}

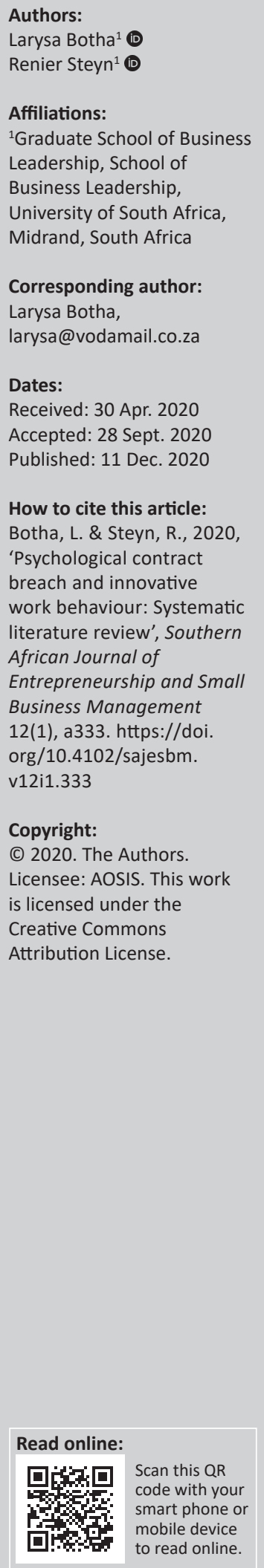

Background: Innovative work behaviour (IWB) is central to organisational success and occurs despite psychological contract breaches (PCBs), which are the norm, rather than the exception.

Aim: The aim of the article is to present a comprehensive review of the conceptualisation of IWB and PCB, specifying the manner in which the concepts are defined and assessed. Consistency in conceptualisation and the standardisation of measurement should contribute to the development of the unified body of knowledge.

Setting: The ways concepts are defined and assessed differ across studies, which challenges researchers and managers as no standard definitions or measurement techniques are available.

Methods: A systematic literature review methodology was followed to gather data, which were analysed by focusing on broad adoption, theoretical coherency and, in the case of measurement, psychometric properties.

Results: In total 14 articles were retrieved that measured the PCB-IWB link. Psychological contract breach is most often defined and measured in terms of Robinson and Morrison's (2000) and Robinson and Rousseau's (1994) conceptualisations, whilst Janssen's (2000) framework is applied to IWB. Reliability information is reported for these measures.

Conclusion: Whilst many definitions and measures of the constructs are used, some are theoretically more comprehensive and some are applied more than others, and these are now stipulated. Managers, consultants and researchers are now empowered to enter the academic debate on the PCB-IWB link and to test substantial and complementary hypotheses that will contribute meaningfully to the existing body of knowledge.

Keywords: psychological contract breach; innovative work behaviour; systematic literature review; conceptualisation; psychometric assessment.

\section{Introduction}

Organisations rely on innovation as a key source of competitiveness and overall organisational success (Bos-Nehles, Renkema \& Janssen 2017; Sanz-Valle \& Jiménez-Jiménez 2018; Veenendaal 2015). In order for innovative strategies to be successful, employees' behaviours must be aligned with such strategies (Bos-Nehles et al. 2017); therefore, 'one option for organisations to become more innovative is to encourage their employees to be innovative' (Agarwal 2014:43). Of note here is that a large part of the needed innovation is achieved beyond research and development departments, with organisations relying on ordinary employees for creativity and innovative thinking (Janssen 2000; Scott \& Bruce 1994). These individuals, operating 'close to the ground', are an invaluable source of information on trends in the market, changes in competition dynamics, opportunities for operational improvements and other important insights. For organisations to benefit from these insights, employees must be willing to engage in innovative work behaviour (IWB; Akhtar, Bal \& Long 2016; Milliken, Morrison \& Hewlin 2003; Morrison 2011; Zagenczyk et al. 2015). As IWB denotes discretionary actions that go beyond the prescribed and are often not directly or explicitly recognised by the formal reward system (Janssen 2000:288), managers have the important task of facilitating such behaviour, which already forms part of the recognised management practices (BosNehles et al. 2017; Sanz-Valle \& Jiménez-Jiménez 2018; Veenendaal 2015). However, understanding of IWB and how it can be influenced and shaped is fragmented and limited (Bos-Nehles et al. 2017).

When studying innovation, the general literature reports many factors that prevent employees from engaging in IWB. Firstly, organisational constraints, including lack of organisational support 
and leadership as well as bureaucracy and the limited availability of resources. Secondly, individual or group constraints, including individual's unwillingness and resistance to change, job stress, destructive competition between group members and interpersonal conflicts (Caniëls \& Rietzschel 2015; Hon \& Lui 2016).

Psychological contract breach (PCB) - the construct of interest in this study - was not mentioned in the sources consulted in the preliminary literature review. The PC concept assumes that employees expect their organisation to meet a large number of obligations as part of the explicit and implicit conditions within the employee-employer relationship (Deery, Iverson \& Walsh 2006; Morrison \& Robinson 1997; Rousseau 1989). Psychological contract breach occurs when employees believe that the organisation or its agent has failed to uphold its obligations (Morrison \& Robinson 1997). Several studies report findings confirming the critical role of met expectations in affecting employee behaviours (Flood et al. 2001). Whilst the PC literature often uses the term PCB and violation interchangeably, Morrison and Robinson (1997) clearly distinguish between the two constructs. Authors argue that breach is a cognitive evaluation that one's organisation has failed to fulfil its obligations, whereas violation is the emotional and affective state that may follow from the individual's perception of breach. In their meta-analysis, Zhao et al. (2007) further report that PCB and violation display characteristics, which suggest that they are distinct, and as such it would be important to pay a specific attention to which construct is studied and measured. The focus of this article is explicitly on breach, not violation.

Perceived as the norm, rather than the exception (Robinson \& Rousseau 1994), a significant amount of research literature is dedicated to PCB and its adverse effects on organisations. In their meta-analysis, Zhao et al. (2007) posit that PCBs are associated with attitude-related (job satisfaction, turnover intention and organisational commitment) and behaviourrelated work outcomes (organisational citizenship behaviour and in-role performance). Similarly, as reported by another stream of research (Hartmann \& Rutherford 2015; Paillé, Raineri \& Valeau 2016; Raja, Johns \& Ntalianis 2004; Rigotti 2009; Suazo 2009; Vander Elst et al. 2016), job satisfaction, decreased organisational commitment, diminished customer-orientated and co-worker-orientated citizenship behaviours, increased absenteeism and actual employee turnover add to a broad range of negative consequences of PCB. Although studies on the effects of PCB on IWB are scant, nearly all researchers report that PCB correlates negatively with IWB (Li et al. 2014; $\mathrm{Ng}$, Feldman \& Lam 2010; Van der Elst et al. 2016), which is consistent with the findings reported in the extant literature.

Some studies, however, show that negative situations can foster innovation and encourage employees' innovative behaviours. Yang and Hung (2015) found that (negative) emotions such as anger or hostility can foster idea generation, which forms part of IWB. Innovation is also triggered when employees experience personal confrontations or organisational uncertainty (Van de
Ven 1986). Despite the negative outcomes generally associated with PCB, it may also lead to positive outcomes such as employees' creativity in search for organisational improvements (Zhou \& George 2001). Zhou and George (2001), however, assert that the organisational context is a key to determine the nature of employees' perceptions; and as such, managers, who have an influence on context, may be instrumental in linking breach with innovation.

The possibility of $\mathrm{PCB}$ resulting in positive employee outcomes, specifically of a behavioural nature, suggests two scenarios - one is probable and the other exceptional. It is apparent that PCB generally results in negative organisational outcomes, and this is well supported by literature. However, there is also a small number of research reports which advocate that PCB may have positive consequences (Kiazad, Seibert \& Kraimer 2014; Van de Ven 1986), including innovation (Niesen et al. 2018b; Zhou \& George 2001). As PCBs seem to be omnipresent and tend to become a norm (Agarwal 2014; Dulac et al. 2008; Jiang, Probst \& Benson 2017; Robinson \& Rousseau 1994; Tziner, Felea \& Vasiliu 2017), identifying the circumstances under which PCB has positive effects, thus, warrants further investigation. This will allow for the development of interventions to manage the environments in which PCB occurs and innovation is needed.

The aim of this article is to comprehensively conceptualise and operationalise IWB and PCB as variables central to organisational survival and employer-employee interactional dynamics. Without clarity on how these variables are defined and measured, researchers will be unable to contribute to the present body of knowledge and, thus, will fail to manage the interaction between these variables scientifically.

\section{Methodology}

In order to ensure that the most important literature is captured in the analysis, a systematic literature review (SLR) methodology was followed:

A systematic review is a review of a clearly formulated question that uses systematic and explicit methods to identify, select, and critically appraise relevant research, and to collect and analyse data from the studies that are included in the review. (Moher et al. 2009:332)

Following such a process increases 'methodological rigour' and provides a 'reliable knowledge base by accumulating knowledge from a range of studies' (Tranfield, Denyer \& Smart 2003:220). The procedure proposed by Nightingale (2009) was followed, in which the aims and objectives of the review, the inclusion-exclusion criteria, how data were identified as well as the plan of the analysis are reflected.

\section{Research objective}

The objective of the SLR was to comprehensively conceptualise and operationalise (through an analysis of measurement) PCB and IWB, given articles in which both constructs are measured. 


\section{Scope of the study}

Only articles published from 1994 onwards were selected. This is the year of publication of the seminal paper of Scott and Bruce (1994) on IWB, after which research on IWB gained momentum (Bos-Nehles et al. 2017).

This date also corresponds with the publication of the longitudinal and definitive study of Robinson and Rousseau (1994) on PCB, which concluded that the prevalence of PCB is (very) high; and it has a significant impact on workplace behaviour.

\section{Inclusion criteria}

Studies included in this review were academic articles published in peer-reviewed journals, published in English, investigating and reporting on the relationship between PCB and IWB and the product of the search terms 'psychological contract breach', 'innovative work behaviour', 'PCB', and 'IWB'.

\section{Search process}

The following keywords were used and combined with the Boolean 'AND' operation: 'psychological contract breach', 'innovative work behaviour', 'PCB' and 'IWB'. It was specified that the keywords needed to be included in the title, abstract and/or keywords of the articles. All retrieved articles were firstly inspected for relevance, including articles that studied close proxies to the search terms. For example, studies used terms 'psychological contract fulfilment' (PCF) rather than PCB and aspects of IWB such as 'idea generation' were included in the analysis. The next step was to ascertain whether the constructs of PCB and IWB were defined and measured independently as variables. This implies that only quantitative research studies were considered.

As an additional step, the reference lists of selected articles were scrutinised to identify more articles that met the requirement of studying both $\mathrm{PCB}$ and IWB as separate variables.

\section{Ethical consideration}

Ethical clearance was granted by the University of South Africa. Ethical clearance number: 2019_SBL_001_CA.

\section{Results}

In the EbscoHost boutique, using the 'SmartText search' option, the search yielded 25 articles. Following the same search procedure in the ProQuest databases, 16 articles were retrieved. The SCOPUS database yielded five articles. The search in Google Scholar yielded 132 results. After screening all the abstracts and removing all duplications, 21 articles remained. Following the full-text screening, 13 articles met the criteria. Only one article was added following a scrutiny of the references of the 13 found articles. The total yield was thus 14 studies. None of these included a meta-analysis of the PCB-IWB link.
Presented below are the definitions of PCB and IWB, as presented in studies analysing the PCB-IWB link. Following that, the ways PCB and IWB were measured are presented, including the findings on the reliability of these instruments.

\section{Conceptualising innovative work behaviour and psychological contract breaches}

Presented in Table 1 are definitions of IWB and PCB and their proxies, as found in studies addressing both concepts. The definitions are presented chronologically.

In seven of the 14 articles, the authors refer to IWB with reference to the three most recognised authors in the IWB field: Farr and West (1990:9), with Janssen (2000:288) adding to that, and the work of De Jong and Den Hartog (2007:43). In five papers, proxies of IWB are presented, such as 'work-role innovation' (Kiazad et al. 2014), 'innovation-related behaviors' ( $\mathrm{Ng}$ et al. 2010), 'creative performance' (Ahmad et al. 2019), 'innovation management' (Bhatnagar 2014) and 'service innovation behavior' (Kim et al. 2017).

Although these substitute terms clearly relate to IWB, theoretically they are most likely distinct. In two papers (Li et al. 2014; Vander Elst et al. 2016), no comprehensive definitions for IWB were presented.

Aligned with PC and PCB theorists, the definitions of PCB and PCF are consistent. In seven of the 14 articles, authors provide direct definitions of PCB as employees' perceptions regarding the extent to which the employer has failed to fulfil its promises and obligations, as found in Morrison and Robinson (1997) and Robinson and Rousseau (1994). In the other seven articles, the PCB is described as the exchange relationship between two parties in which one party, the organisation, fails to provide reciprocal returns. Although cited from various authors, the origin of these definitions again goes back to the conceptualisations of Morrison and Robinson (1997) and Robinson and Rousseau (1994).

\section{Operationalising innovative work behaviour and psychological contract breaches}

Details of the measurement of IWB and PCB and their proxies are presented in Table 2.

Of the 14 studies, four used the nine-item scale by Janssen (2000), three adopted the 10-item scale by De Jong and Den Hartog (2010) and two used the nine-item scale by Scott and Bruce (1994). Three studies utilised the shortened versions of scales by De Jong and Den Hartog (2010) and Scott and Bruce (1994), stating the motive as practical considerations. In the remainder of the articles the proxies of IWB were measured by instruments developed by other authors. The Cronbach's $\alpha$ values varied between 0.77 and 0.95 , with an average of 0.90 . The users of Janssen's (2000) instrument report $\alpha$ s varying between 0.92 and 0.94 . 
Of the 14 studies cited, in six instances PCB was measured with the Robinson and Morrison's (2000) scale, four using the standard five-item scale and two the shortened four-item version. In most of the other studies (seven) the authors adapted scales from other researchers; and in one study (Ramamoorthy et al. 2005), the researcher developed his own scale. The Cronbach's $\alpha$ values varied between 0.76 and 0.97 , with an average of 0.87 . The users of Robinson and Morrison's (2000) scale report as varying between 0.82 and 0.97 .

TABLE 1: Definitions of innovative work behaviour and psychological contract breaches and their proxies.

\begin{tabular}{|c|c|c|}
\hline Author & Constructs and proxies & Definitions or explanations of concepts \\
\hline \multirow[t]{2}{*}{ Janssen (2000) } & IWB & $\begin{array}{l}\text { IWB is defined as the intentional creation, introduction and application of new ideas within a work role, group or } \\
\text { organisation, in order to benefit role performance, the group, or the organisation. (p. 288) }\end{array}$ \\
\hline & $\begin{array}{l}\text { Proxy to PCF: effort-reward } \\
\text { fairness (E-RF) }\end{array}$ & $\begin{array}{l}\text { In line with social exchange theory (Blau 1964), when employees' efforts are fairly rewarded in their social exchange } \\
\text { relationships, employees are willing to reciprocate with certain extra-role behaviours, such as innovative activities. } \\
\text { (p. 290) }\end{array}$ \\
\hline \multirow{2}{*}{$\begin{array}{l}\text { Ramamoorthy et al. } \\
\text { (2005) }\end{array}$} & IWB & Authors adopted the definition of Janssen (2000). \\
\hline & $\begin{array}{l}\text { Proxy to PCF: met expectations } \\
\text { and obligation to innovate }\end{array}$ & $\begin{array}{l}\text { Explained as an aspect of the PC (Rousseau 1990), met expectations refer to 'an employee's assessment and belief that } \\
\text { his/her expectations have been satisfied through their work experience' ( } p .143 \text { ). Whilst referring to Flood et al. (2001), } \\
\text { the authors explain that the met expectations influence the employees' perceived obligations to contribute to the } \\
\text { organisation by means of IWB. }\end{array}$ \\
\hline
\end{tabular}

$\begin{array}{ll}\text { Ng et al. (2010) } & \begin{array}{l}\text { Proxy to IWB: innovation- } \\ \text { related behaviours }\end{array}\end{array}$

PCB

Newton, Blanton and $\quad$ IWB

Will (2011)

PCF

$\begin{array}{ll}\text { Li et al. (2014) } & \text { IWB } \\ & \text { PCF } \\ & \\ \text { Agarwal and Bhargava } & \text { IWB } \\ \text { (2014) } & \text { PCB } \\ \text { Agarwal (2014) } & \text { IWB } \\ & \text { PCF }\end{array}$

Bhatnagar (2014)

Based on Parker, Williams and Turner's (2006) concept of proactive behaviour, innovation-related behaviour is operationalised as proactive idea implementation which goes beyond merely coming up with creative ideas to involve (1) sharing ideas with others and spreading the innovation throughout the organisation and (2) working to implement those innovations individually or in the group. (p. 745)

Conceptualised by Robinson (1996), when employees feel valued and respected by their employers, they are likely to reciprocate with positive attitudes and behaviours. By contrast, when employees perceive that their organisations have failed to fulfil their promises, PCB is understood to have occurred. (p. 745)

Authors adopted the definition of Janssen (2000).

The explanation is derived from conceptualisations by Robinson and Morrison (1995) and Robinson and Rousseau (1994), stating that the perception of the degree of fulfilment, change, breach or violation of the PC refers to the instance where the employer may fail to live up to some aspect of their obligations and the employee, in turn, believes less is owed to their employer. (p. 29)

No definition was provided. However, the measure by Scott and Bruce (1994) was used. It is assumed that the authors subscribed to Scott and Bruce's definition of IWB.

Authors adopted the definition by Henderson et al. (2008) who refer to PCF as a perceived balance in exchange relationship between an employee and the organisation. (p. 82)

Authors adopted the definition of Janssen (2000).

Authors adopted the definition of Morrison and Robinson (1997).

Author adopted the definition of Janssen (2000).

PCF is based on PC construct, which relates to the perception of justice of individual outcomes and encompasses not only obligations established via a formal or an implied contract, but also via more implicit means. (Morrison \& Robinson 1997)

Proxy to IWB: management of Based on conceptualisations of Jansen et al. (2009), management of innovation is defined as 'a dynamic capability that innovation refers to the routines and processes by which organisations mobilise, synchronise and assimilate dispersed contradictory refers to the routines and processes by which organisations mobilise, synchronise and assimilate dispersed contradictory as a vesferentiated exploratory and exploitative units'. Some literature perceives the management of innovations as a vehicle to deliver improvements in organisational effectiveness. (Bhatnagar 2014:1401)

Proxy to PCF: reward and recognition

Author adopted the definition of Saks (2006), which refers to reward and recognition as 'a sense of return on investments which can come from external rewards and recognition in addition to meaningful work'. It is operationalised in terms of pay raises, job security, promotions, more freedom and opportunities, respect from co-workers, training and pay raises, job security, promotions, more
development opportunities, etc. (p. 1399)

Kiazad et al. (2014) Proxy to IWB: work-role

Based on the work of Axtell et al. (2000) and Welbourne, Johnson and Erez (1998), work-role innovation is defined as 'extra-role employee behaviour that involves the introduction and implementation of novel ideas to improve existing work processes and routines'. (p. 536)

Authors adopted the definition of Morrison and Robinson (1997).

Not provided, but introduced as a sub-construct within the behavioural coping reactions variable.

Authors adopted the definition of Robinson and Morrison (2000), which refers to employees' perception that the employer failed to fulfil his or her side to the deal. (p. 103)

Niesen et al. (2018a) Proxy to IWB: idea generation

PCB

Based on Farr and West (1990) and Hammond et al. (2011), idea generation is explained as a two-stage process; first as generation of completely novel ideas (i.e. creativity) and then as generation of adopted ideas that apply existing systems to new situations. (p. 2)

Adapted from Robinson and Rousseau's (1994) conceptualisation, 'PCB occurs when one party perceives another to have broken their promise'. (p. 3)

Niesen et al. (2018a) Proxy to IWB: idea generation and idea implementation

PCB

IWB is considered 'a construct that captures all behaviours through which employees can contribute to the innovation process' (De Jong \& Den Hartog 2007:43). Two phases are typically distinguished in the innovation process, namely, the generation of ideas and subsequently the implementation of these ideas. Idea generation concerns the creation the generation of ideas and subsequently the implementation of these ideas. Idea generation concerns the creation Idea implementation refers to the adaptation and convergence of these ideas with daily work practices. (p. 176) Authors adopted the definition of Robinson and Morrison (2000).

Kim, Karatepe and Lee Proxy to IWB: service (2017) innovation PCB

Ahmad et al. (2019)

Proxy IWB: creative performance PCF

Based on Abbas and Raja (2015), service innovation behaviour refers to the ability of employees to generate novel ideas for service improvement and to adopt other's ideas which are new in the current workplace. (p. 307)

Authors adopted the definition of Robinson and Rousseau (1994)

Based on Oldham and Cummings (1996), creative performance is described to be associated with the novel and unique ideas and processes which are useful for organisations to thrive in a competitive environment. (p. 102)

PCF is defined as promissory understandings and beliefs of an employee about the chances of fulfilment of the pledges made by their organisation. (Rousseau 1995:99)

Note: Please see the full reference list of the article, Botha, L. \& Steyn, R., 2020, 'Psychological contract breach and innovative work behaviour: Systematic literature review', Southern African Journal of Entrepreneurship and Small Business Management 12(1), a333. https://doi.org/10.4102/sajesbm.v12i1.333, for more information.

IWB, innovative work behaviour; PCB, psychological contract breach; PCF, psychological contract fulfilment. 
TABLE 2: Measurement of innovative work behaviour and psychological contract breaches and their proxies.

\begin{tabular}{|c|c|c|c|}
\hline Author & Constructs and proxies & Instruments & $\alpha$ \\
\hline \multirow[t]{2}{*}{ Janssen (2000) } & PCF as effort-reward fairness & 6-item scale of VanYperen $(1996,1998)$ & 0.90 \\
\hline & IWB & 9-item scale of Scott and Bruce (1994) & 0.95 \\
\hline \multirow[t]{2}{*}{ Ramamoorthy et al. (2005) } & PCF as met expectations and obligation to innovate & 12-item scale of Ramamoorthy et al. (2005) & 0.76 \\
\hline & IWB & 9-item scale of Janssen (2000) & 0.94 \\
\hline \multirow[t]{2}{*}{ Ng et al. (2010) } & PCB & 5-item scale of Robinson and Morrison (2000) & 0.97 \\
\hline & IWB as innovation-related behaviours & 5-item scale of Parker et al. (2006) & 0.83 (ave) \\
\hline \multirow[t]{2}{*}{ Newton et al. (2011) } & PCF & $\begin{array}{l}4 \text { of } 6 \text { dimensions of PCF - stability, scope, tangibility and time frame were } \\
\text { measured with } 14 \text {-item scale of Sels, Janssens and Van Den Brande (2004), } \\
\text { authors developed } 6 \text {-item instrument for other two dimensions - focus } \\
\text { (5-item scale) and volition (1-item scale) }\end{array}$ & $\begin{array}{l}\text { All alphas } \\
\quad>0.80\end{array}$ \\
\hline & IWB & Shortened to 8-item scale of Janssen (2000) & 0.92 \\
\hline \multirow[t]{2}{*}{ Li et al. (2014) } & PCF & 4-item scale of Henderson et al. (2008) & 0.84 \\
\hline & IWB & Shortened to 6-item scale of Scott and Bruce (1994) & 0.93 \\
\hline \multirow[t]{2}{*}{ Agarwal and Bhargava (2014) } & PCB & Scale of Turnley and Feldman (1999) (based on Rousseau (1990)) & 0.89 \\
\hline & IWB & 9-item scale of Janssen (2000) & 0.92 \\
\hline Agarwal (2014) & IWB & 9-item scale of Janssen (2000) & 0.92 \\
\hline \multirow[t]{2}{*}{ Bhatnagar (2014) } & PCF as reward and recognition & 10-item scale of Saks (2006) & 0.76 \\
\hline & IWB as management of innovations & 10-item scale of Medina and Rufin (2009) & 0.77 \\
\hline \multirow[t]{2}{*}{ Kiazad et al. (2014) } & PCB & Facet-based measure of Kickul et al. (2001) & N/A \\
\hline & IWB as work-role innovation & 4-item scale of Welbourne et al. (1998) & 0.89 \\
\hline \multirow[t]{2}{*}{ Vander Elst et al. (2016) } & PCB & \multirow{2}{*}{$\begin{array}{l}\text { Both constructs were measured using selection of items from validated } \\
\text { original scales }\end{array}$} & 0.90 \\
\hline & IWB & & 0.90 \\
\hline \multirow[t]{2}{*}{ Niesen et al. (2018a) } & PCB & Shortened to 4-item scale of Robinson and Morrison (2000) & 0.87 \\
\hline & IWB as idea generation & 4-item scale from IWB instrument of De Jong and Den Hartog (2010) & 0.90 \\
\hline \multirow[t]{3}{*}{ Niesen et al. (2018b) } & PCB & 5-item scale of Robinson and Morrison (2000) & 0.82 \\
\hline & IWB as idea generation and idea implementation & 4 items for IG of De Jong and Den Hartog (2010) & 0.87 \\
\hline & & 5 items for II of De Jong and Den Hartog (2010) & 0.90 \\
\hline \multirow[t]{2}{*}{ Kim et al. (2017) } & PCB & 5-item scale of Robinson and Morrison (2000) & 0.88 \\
\hline & IWB as service innovation & $\begin{array}{l}\text { 6-item scale of Hu, Horng and Sun (2009) (modified from Scott and } \\
\text { Bruce [1994]) }\end{array}$ & 0.87 \\
\hline
\end{tabular}

Note: Please see the full reference list of the article, Botha, L. \& Steyn, R., 2020, 'Psychological contract breach and innovative work behaviour: Systematic literature review', Southern African Journal of Entrepreneurship and Small Business Management 12(1), a333. https://doi.org/10.4102/sajesbm.v12i1.333, for more information.

IWB, innovative work behaviour; PCB, psychological contract breach; PCF, psychological contract fulfilment.

\section{Discussion}

\section{Definitions}

The definition of Janssen (2000:288) is the most often used to describe IWB and reflects the multistage theorising. Most of the other definitions also reflect a multistage sequential conceptualisation of IWB, but researchers differ on the labelling of the stages as well as the number of the stages. Although often presented as discrete stages (De Jong \& Den Hartog 2010; Janssen 2000; Kleysen \& Street 2001; Scott \& Bruce 1994), the empirical verification of this conceptualisation often fails, resulting in researchers settling for describing IWB with fewer stages or as a single construct. Scott and Bruce (1994) contribute this to the idea that innovation is characterised by discontinued activities, where employees may be involved in several of these stages simultaneously. De Jong and Den Hartog (2010) as well as Janssen (2000) support Scott and Bruce's (1994) explanation for testing less complex models.

Some of the studies located during the scrutiny of the literature on the PCB-IWB link define proxies for IWB. Being theoretically divorced from the concept, these definitions should not be considered when defining IWB.
By example, focusing on innovation (see Ahmad et al. 2019), 'creative performance' refers primarily to creativity, which represents only the initial stage of IWB. References to these proxies account for subsets of IWB, primarily the creative stage of the construct.

Given the simplicity, theoretical soundness and adoption as seminal in the field of IWB, the following definition from Janssen (2000) is proposed as the standard definition of IWB:

IWB is defined as the intentional creation, introduction and application of new ideas within a work role, group or organisation, in order to benefit role performance, the group, or the organisation. (p. 288)

Unlike the disparity in defining the IWB construct, there is more consistency in defining the PCB. The definition used most often is that of Morrison and Robinson (1997), which evolved from Robinson and Rousseau's (1994) definition, also often referred to. This seems to be the standard definition, and as such the following definition of PCB by Robinson and Rousseau (1994) is suggested:

PCB is the employee's perception regarding the extent to which the organization has failed to fulfil its promises or obligations. (p. 247) 
Several proxies for PCB are presented as PCF and these are 'effort-reward fairness' (Janssen 2000), 'met expectations', 'obligations to innovate' (Ramamoorthy et al. 2005) and 'reward and recognition' (Bhatnagar 2014). The utility of proxies will be explained better when dealing with the global and composite measurement of PCB.

\section{Operationalisation}

In general, consistency in conceptualisation and the standardisation of measurement instruments should contribute to the development of the body of knowledge (Babbie \& Mouton 2011). With reference to PCB, Conway and Briner (2005:94) state that many matters remain unresolved as 'there are a variety of measures for assessing both breach and the contents of psychological contracts, showing there is no single, agreed upon measure of either of these constructs'.

The measurement of IWB should focus on the single construct and not on its discreet stages (Scott \& Bruce 1994). Scott and Bruce (1994) argue that innovation comprises discontinued activities, which are often performed by employees simultaneously. It is suggested that the measure of IWB, as a single construct, proposed by Janssen (2000) should be used as the standard. As presented above, the instrument is used frequently, it is theoretically aligned to most of the other researchers' thoughts in the field and has sound psychometric properties. The reported reliability of this measure varies between 0.92 and 0.94 . Researchers are alerted not to use proxies of IWB (e.g. creativity, idea generation and idea implementation), as these often measure only part of the construct. Furthermore, IWB does not seem to empirically consist of discrete stages; therefore, total scores rather than stage scores should be included in models (Steyn \& De Bruin 2019). This emphasises the inadequacies of proxies as measurement of IWB.

With regard to $\mathrm{PCB}$, the picture is more complex. Firstly, it is important to note that $\mathrm{PCB}$ and $\mathrm{PCF}$ are used as the end point of the same scale, with the naming convention dependent on the hypotheses being tested.

Secondly, it is important to consider composite or global measures (see Zhao et al. 2007). Composite measures draw on a collection of questions related to the breach of specific expectations, such as related to training or rewards, compared to global measures, which use questions such as 'Almost all the promises made by my employer during recruitment have been kept thus far' (reverse scored; Robinson \& Morrison 2000). Except for one article (see Kiazad et al. 2014), where the authors used a PCF composite measure of Kickul et al. (2001), all other studies sampled used the global approach to calculating the PCB score, which is in line with Zhao et al.'s (2007) recommendation to focus on these types of measure.

Given the aforementioned, the five-item PCB measure of Robinson and Morrison (2000) is proposed, because of its seminal status, the fact that it is a global measure and has acceptable psychometric characteristics. Apart from consisting of only five items, the $\alpha$ coefficients reported varied between 0.82 and 0.97 .

\section{Conclusion}

This research makes a valuable contribution to the present body of knowledge by following the SLR methodology to comprehensively summarise and critically evaluate the conceptualisation and operationalisation of two important organisational behaviour constructs. Through the analyses of studies involving the PCB-IWB link, the research distilled definitions as well as appropriate measures of each. The adoption of the conceptualisations of Janssen (2000; IWB) and Robinson and Rousseau (1994; PCB) is proposed as well as the measurements provided by Janssen (2000) (IWB) and Robinson and Morrison (2000; $\mathrm{PCB})$. Given acceptance of these suggestions, the body of knowledge in the PCB-IWB link should be placed on a solid basis. Using the same concepts as well as measurements will facilitate comparisons between studies and improving the quality of meta-analyses.

\section{Managerial implications}

Managers are now equipped with comprehensive and theoretically sound definitions and, by implication, conceptualisations of concepts central to organisational success (i.e. IWB) and one endemic to the organisational setting (i.e. PCB). This knowledge is foundational to the management of each and, as reported above, both constructs, PCB and IWB, are related.

Additional to the definitions, managers and, more pertinently, organisational behaviour consultants and researchers are informed on the most used, empirically sound and theory-based instruments available to measure both PCB and IWB. This will not only allow them to measure these constructs in a sound manner but also align their research to the current body of knowledge.

\section{Limitations and suggestions for future research}

This SLR focused on articles involving the PCB-IWB link. This focus seemed appropriate when the study was conducted and made the amount of information to deal with manageable. However, focusing within an SLR on PCB and IWB independently may have yielded more complete results. Future researchers are advised to follow that route, should they consider similar studies. Finally, researchers are also encouraged to collect data not only through self-reporting perspective but also through perspectives of observers, co-workers and supervisors.

\section{Acknowledgements Competing interests}

The authors have declared that no competing interests exist. 


\section{Authors' contributions}

All authors contributed equally to this work.

\section{Funding information}

This research received no specific grant from any funding agency in the public, commercial or non-profit sectors.

\section{Data availability statement}

The authors confirm that the data supporting the findings of this study are available within the article.

\section{Disclaimer}

The views and opinions expressed in this article are those of the authors and do not necessarily reflect the official policy or position of any affiliated agency of the authors.

\section{References}

Abbas, M. \& Raja, U., 2015, 'Impact of psychological capital on innovative performance and job stress', Canadian Journal of Administrative Sciences 32(2), 128-138. https://doi.org/10.1002/cjas.1314

Agarwal, U.A., 2014, 'Linking justice, trust and innovative work behaviour to work engagement', Personnel Review 43(1), 41-73. https://doi.org/10.1108/pr-022012-0019

Agarwal, U.A. \& Bhargava, S., 2014, 'The role of social exchange on work outcomes: A study of Indian managers', The International Journal of Human Resource study of Indian managers, The International Journal of Human Resource
Management 25(10), 1484-1504. https://doi.org/10.1080/09585192.2013.870316

Ahmad, I., Donia, M., Asadullah, K. \& Waris, M., 2019, 'Do as I say and do as I do? The mediating role of psychological contract fulfillment in the relationship between ethical leadership and employee extra-role performance', Personnel Review 48(1) 98-117. https://doi.org/10.1108/PR-12-2016-0325

Akhtar, M.N., Bal, M. \& Long, L., 2016, 'Exit, voice, loyalty, and neglect reactions to frequency of change, and impact of change', Employee Relations 38(4), 536-562. https://doi.org/10.1108/ER-03-2015-0048

Axtell, C.M., Holman, D.J., Unsworth, K.L., Wall, T.D., Waterson, P.E. \& Harrington, E. 2000 , 'Shopfloor innovation: Facilitating the suggestion and implementation of ideas', Journal of Occupational and Organizational Psychology 73(3), 265-285. https://doi.org/10.1348/096317900167029

Babbie, E. \& Mouton, J., 2011, The practice of social research, 2nd edn., Oxford University Press Southern Africa, Cape Town.

Bhatnagar, J., 2014, 'Mediator analysis in the management of innovation in Indian knowledge workers: The role of perceived supervisor support, psychological
contract, reward and recognition and turnover intention', International Journal of contract, reward and recognition and turnover intention', International Journal of Human Resource Man

Blau, P., 1964, Power and exchange in social life, John Wiley \& Sons, New York, NY.

Bos-Nehles, A., Renkema, M. \& Janssen, M., 2017, 'HRM and innovative work behaviour: A systematic literature review', Personnel Review 46(7), 1228-1253. https://doi.org/10.1108/PR-09-2016-0257

Caniëls, M.C.J. \& Rietzschel, E.F., 2015, 'Organizing creativity: Creativity and innovation under constraints', Creativity and Innovation Management 24(2), 184-196. https://doi.org/10.1111/caim.12123

Conway, N. \& Briner, R.B., 2005, Understanding psychological contracts at work. A critical evaluation of theory and research, Oxford University Press, Oxford.

De Jong, J.P.J. \& Den Hartog, D.N., 2007, 'How leaders influence employees' innovative behaviour', European Journal of Innovation Management 10(1), 41-64. https:// doi.org/10.1108/14601060710720546

De Jong, J.P.J. \& Den Hartog, D.N., 2010, 'Measuring innovative work behaviour', Creativity and Innovation Management 19(1), 23-36. https://doi.org/10. 1111/j.1467-8691.2010.00547.x

Deery, S.J., Iverson, R.D. \& Walsh, J.T., 2006, 'Toward a better understanding of psychological contract breach: A study of customer service employees', Journal of Applied Psychology 91(1), 166.

Dulac, T., Coyle-Shapiro, J.A-M., Henderson, D.J. \& Wayne, S.J., 2008, 'Not al responses to breach are the same: The interconnection of social exchange and psychological contract processes in organizations', Academy of Management Journal 51(6), 1079-1098.

Farr, J.L. \& West, M.A., 1990, Innovation and creativity at work: Psychological and organisational strategies, J.L. Farr \& M.A. West (eds.), Wiley, Chichester.

Flood, P.C., Turner, T., Ramamoorthy, N. \& Pearson, J., 2001, 'Causes and consequences of psychological contracts among knowledge workers in the high technology and financial services industries', International Journal of Human Resource Management 12(7), 1152-1165. https://doi.org/10.1080/09585190110068368
Hammond, M.M., Neff, N.L., Farr, J.L., Schwall, A.R. \& Zhao, X., 2011, 'Predictors of individual-level innovation at work: A meta-analysis', Psychology of Aesthetics, Creativity, and the Arts 5(1), 90-105. https://doi.org/10.1037/a0018556

Hartmann, N.N. \& Rutherford, B.N., 2015, 'Psychological contract breach's antecedents and outcomes in salespeople: The roles of psychological climate, job attitudes, and turnover intention', Industrial Marketing Management 51, 158-170. https:// doi.org/10.1016/j.indmarman.2015.07.017

Henderson, D.J., Wayne, S.J., Shore, L.M., Bommer, W.H. \& Tetrick, L.E., 2008, 'Leadermember exchange, differentiation, and psychological contract fulfillment: A multilevel examination', Journal of Applied Psychology 93(6), 1208-1219. https:// multilevel examination', Journd
doi.org/10.1037/a0012678

Hon, A.H.Y. \& Lui, S.S., 2016, 'Employee creativity and innovation in organizations', International Journal of Contemporary Hospitality Management 28(5), 862-885. https://doi.org/10.1108/ijchm-09-2014-0454

Hu, M.-L., Horng, J.-S. \& Sun, Y.-H., 2009, 'Hospitality teams: Knowledge sharing and service innovation performance', Tourism Management 30(1), 41-50. https://doi. org/10.1016/j.tourman.2008.04.009

Jansen, J.J.P., Tempelaar, M.P., Van den Bosch, F.A.J. \& Volberda, H.W., 2009, 'Structura differentiation and ambidexterity: The mediating role of integration mechanisms', Organization Science 20(4), 797-811. https://doi.org/10.1287/orsc.1080.0415

Janssen, O., 2000, 'Job demands, perceptions of effort-reward fariness and innovative work behaviour', Journal of Occupational and Organizational Psychology 73(3), 287-302. https://doi.org/10.1348/096317900167038

Jiang, L., Probst, T.M. \& Benson, W.L., 2017, 'Organizational context and employee reactions to psychological contract breach: A multilevel test of competing theories', Economic and Industrial Democracy 38(3), 513-534. https://doi.org/ theories', Economic and Industrid
$10.1177 / 0143831 \times 15579288$

Kiazad, K., Seibert, S.E. \& Kraimer, M.L., 2014, 'Psychological contract breach and employee innovation: A conservation of resources perspective', Journal of Occupational and Organizational Psychology 87(3), 535-556. https://doi. org/10.1111/joop.12062

Kickul, J.R. \& Lester, S.W., 2001, 'Broken promises: Equity sensitivity as a moderator between psychological contract breach and employee attitudes and behavior', Journal of Business and Psychology 16(2), 191-217. https://doi.org/10.1023/A: Journal of Business

Kickul, J.R., Neuman, G Parker, C. \& Finkl, J, 2001, 'Settling the score: The role of organizational justice in the relationship between psychological contract breach and anticitizenship behavior', Employee Responsibilities and Rights Journal 13(2), 77-93. https://doi.org/10.1023/A:1014586225406

Kim, T.T., Karatepe, O.M. \& Lee, G., 2017, 'Psychological contract breach and service innovation behavior: Psychological capital as a mediator', Service Business 12(2), 1-25. https://doi.org/10.1007/s11628-017-0347-4

Kleysen, R.F. \& Street, C.T., 2001, 'Toward a multi-dimensional measure of individual innovative behavior', Journal of Intellectual Capital 2(3), 284-296. https://doi. org/10.1108/EUM0000000005660

Li, H., Feng, Z., Liu, C. \& Cheng, D., 2014, 'The impact of relative leader-member exchange on employees' work behaviors as mediated by psychological contract fulfillment', Social Behavior and Personality: An International Journal 42(1), fulfillment', Social Behavior and Personality: An
79-88. https://doi.org/10.2224/sbp.2014.42.1.79

Medina, C. \& Rufin, R., 2009, 'The mediating effect of innovation in the relationship between retailers' strategic orientations and performance', International Journal of Retail \& Distribution Management 37(7), 629-655. https://doi. org/10.1108/09590550910964639

Milliken, F.J., Morrison, E.W. \& Hewlin, P.F., 2003, 'An exploratory study of employee silence: Issues that employees don't communicate upward and why', Journal of Management Studies 40(6), 1453-1476. https://doi.org/10.1111/1467-6486.00387

Moher, D., Liberati, A., Tetzlaff, J., Altman, D.G. \& The PRISMA Group, 2009, 'Preferred reporting items for systematic reviews and meta-analyses: The PRISMA statement', British Medical Journal 339(7716), 332-336. https://doi.org/10.1371/ journal.pmed.1000097

Morrison, E.W., 2011, 'Employee voice behavior: Integration and directions for future research', Academy of Management Annals 5(1), 373-412. https://doi.org/10.10 80/19416520.2011.574506

Morrison, E.W. \& Robinson, S.L., 1997, 'When employees feel betrayed: A model of how psychological contract violation develops', Academy of Management Journal 22(1), 226-256. https://doi.org/10.5465/AMR.1997.<strong>9707180265</strong>

Newton, S.K., Blanton, J.E. \& Will, R., 2011, 'Innovative work and citizenship behaviors from information technology professionals: Effects of their psychological contract', Information Resources Management Journal 21(4), 27-48. https://doi. org/10.4018/irmj.2008100102

Ng, T.W.H., Feldman, D.C. \& Lam, S.S.K., 2010, 'Psychological contract breaches, organizational commitment, and innovation-related behaviors: A latent growth modeling approach', Journal of Applied Psychology 95(4), 744-751. https://doi. org/10.1037/a0018804

Niesen, W., Van Hootegem, A., Battistelli, A., De Witte, H. \& Handaja, Y, 2018a, 'Quantitative and qualitative job insecurity and idea generation: The mediating role of psychological contract breach', Scandinavian Journal of Work and Organizational Psychology 3(1), 3. https://doi.org/10.16993/sjwop.36

Niesen, W., Van Hootegem, A., Vander Elst, T., Battistelli, A. \& De Witte, H., 2018b, 'Job insecurity and innovative work behaviour: A psychological contract perspective', Psychologica Belgica 57(4), 174-189. https://doi.org/10.5334/pb.381

Nightingale, A., 2009, 'A guide to systematic literature reviews', Surgery (Oxford) 27(9), 381-384. https://doi.org/10.1016/j.mpsur.2009.07.005 
Oldham, G.R. \& Cummings, A., 1996, 'Employee creativity: Personal and contextual factors at work', Academy of Management Journal 39(3), 607-634. https://doi. factors at work', Acader
org $/ 10.2307 / 256657$

Paillé, P., Raineri, N. \& Valeau, P., 2016, 'The effects of the psychological contract among professional employees working in non-professional organizations', Relations Industrielles/Industrial Relations 71(3), 521-543, viewed 12 December 2019, from http://eds.b.ebscohost.com/eds/detail/detail?vid=1\&sid=672334952019, from http://eds.b.ebscohost.com/eds/detail/detail?vid=1\&sid=67233495050c-4f5d-a852-0d2bea71dd04\%40sessionmgr104\&bdata=JkF1dGhUeXBIPW
b2tpZSxpcCx1aWQmc2I0ZT1IZHMtbGI2ZQ\%3D\%3D\#AN=118456544\&db=bth.

Parker, S.K., Williams, H.M. \& Turner, N., 2006, 'Modeling the antecedents of proactive behavior at work', Journal of Applied Psychology 91(3), 636-652. https://doi. org/10.1037/0021-9010.91.3.636

Raja, U., Johns, G. \& Ntalianis, F., 2004, 'The impact of personality on psychological contracts', Academy of Management Journal 47(3), 350-367. https://doi. $\operatorname{org} / 10.5465 / 20159586$

Ramamoorthy, N., Flood, P., Slattery, T. \& Sardessai, R., 2005, 'Determinants of innovative work behaviour: Development and test of an integrated model', Creativity and Innovation Management 14(2), 142-150, viewed 18 November 2019, from http:// papers.ssrn.com/sol3/papers.cfm?abstract id $=722247 \% 5$ Cnhttp: $/ /$ www. researchgate net/profile/Patrick_Flood2/publication/227922314 Determinants of_Innovative_Work_Behaviour_Development_and_Test_of_an_Integrated Mödel/links/Ofcfd50c22 fa132d2fo00000.pdf.

Rigotti, T., 2009, 'Enough is enough? Threshold models for the relationship between psychological contract breach and job-related attitudes', European Journal of Work and Organizational Psychology 18(4), 442-463. https://doi.org/10. 1080/13594320802402039

Robinson, S.L., 1996, 'Trust and breach of the psychological contract', Administrative Science Quarterly 41(4), 574-599. https://doi.org/10.2307/2393868

Robinson, S.L. \& Morrison, E.W., 1995, 'Psychological contracts and OCB: The effect of unfulfilled obligations on civic virtue behavior', Journal of Organizational Behavior 16(3), 289-298. https://doi.org/10.1002/job.4030160309

Robinson, S.L. \& Morrison, E.W., 2000, 'The development of psychological contract breach and violation: A longitudinal study', Journal of Organizational Behavio 21(5), 525-546. https://doi.org/10.1002/1099-1379(200008)21:5\%3C525::AIDJOB40\%3E3.0.CO;2-T

Robinson, S.L. \& Rousseau, D.M., 1994, 'Violating the psychological contract: Not the exception but the norm', Journal of Organizational Behavior 15(December 1992) 245-259. https://doi.org/10.1002/job.4030150306

Rousseau, D.M., 1990, 'New hire perceptions of their own and their employer's obligations: A study of psychological contracts', Journal of Organizational Behavior 11(5), 389-400. https://doi.org/10.1002/job.4030110506

Rousseau, D.M., 1989, 'Psychological and implied contracts in organizations', Employee Responsibilities and Rights Journal 2(2), 121-139. https://doi. org/10.1007/BF01384942

Rousseau, D.M., 1995, Psychological contracts in organizations: Understanding written and unwritten agreements, Sage, Thousand Oaks, CA. https://doi. org/10.4135/9781452231594

Saks, A.M., 2006, 'Antecedents and consequences of employee engagement revisited', Journal of Managerial Psychology 21(7), 600-619. https://doi.org/10.1108/ JOEPP-06-2018-0034

Sanz-Valle, R. \& Jiménez-Jiménez, D., 2018, 'HRM and product innovation: Does innovative work behaviour mediate that relationship?', Management Decision 56(5), MD-04-2017-0404. https://doi.org/10.1108/MD-04-2017-0404

Scott, S.G. \& Bruce, R.A., 1994, 'Determinants of innovative behavior: A path model of individual innovation in the workplace', Academy of Management Journal 37(3), 580-607. https://doi.org/10.2307/256701
Sels, L., Janssens, M. \& Van Den Brande, I., 2004, 'Assessing the nature of psychological contracts: A validation of six dimensions', Journal of Organizational Behavior 25(4), 461-488. https://doi.org/10.1002/job.250

Steyn, R. \& De Bruin, G., 2019, 'The structural validity of the innovative work behaviour questionnaire: Comparing competing factorial models', The Southern African Journal of Entrepreneurship and Small Business Management 11(1), 1-11. https:// doi.org/10.4102/sajesbm.v11i1.291

Suazo, M.M., 2009, 'The mediating role of psychological contract violation on the relations between psychological contract breach and work-related attitudes and behaviors', Journal of Managerial Psychology 24(2), 136-160. https://doi. org/10.1108/02683940910928856

Tranfield, D., Denyer, D. \& Smart, P., 2003, 'Towards a methodology for developing evidence-informed management knowledge by means of systematic review', British Journal of Management 14, 207-222. https://doi. org/10.1086/167341

Turnley, H.W. \& Feldman, C.D., 1999, 'The impact of psychological contract violations on exit, voice, loyalty, and neglect', Human Relations 52(7), 895-922. https://doi. org/10.1177/001872679905200703

Tziner, A., Felea, M. \& Vasiliu, C., 2017, 'Psychological contract breach, leader-member exchange, perceived ethical climate and organisational justice: Are they interrelated and how? Journal of East European Management Studies 22(1), 63-82. https://doi.org/10.5771/1862-0019-2017-1-63

Van de Ven, A.H., 1986, 'Central problems in the management of innovation', Management Science 32(5), 590-607. https://doi.org/10.1287/mnsc.32.5.590

Van der Elst, T., De Cuyper, N., Baillien, E., Niesen, W. \& De Witte, H., 2016, 'Perceived control and psychological contract breach as explanations of the
relationships between job insecurity, job strain and coping reactions: Towards a

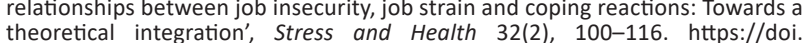
org/10.1002/smi.2584

Van Yperen, N.W., 1996, 'Communal orientation and the burnout syndrome among nurses: A replication and extension', Journal of Applied Social Psychology 26(4), 338-354. https://doi.org/10.1111/j.1559-1816.1996.tb01853.x

Van Yperen, N.W., 1998, 'Informational support, equity and burnout: The moderating effect of self-efficacy', Journal of Occupational \& Organizational Psychology Psychology 71(1), 29-33. https://doi.org/10.1111/j.2044-8325.1998.tb00660.x

Veenendaal, A.A.R., 2015, Enhancing innovation at work through human resource management, University of Twente, Netherlands, viewed 08 April 2020, from http://doc.utwente.nl/95750/1/thesis_A_Veenendaal.pdf

Welbourne, T.M., Johnson, D.E. \& Erez, A., 1998, 'The role-based performance scale: Validity analysis of a theory-based measure', Academy of Management Journa 41(5), 540-555, viewed 09 March 2020, from http://www.jstor.org/ stable/256941

Yang, J.S. \& Hung, H.V., 2015, 'Emotions as constraining and facilitating factors for creativity: Companionate love and anger', Creativity and Innovation Management 24(2), 217-230. https://doi.org/10.1111/caim.12089

Zagenczyk, T.J., Cruz, K.S., Cheung, J.H., Scott, K.L., Kiewitz, C. \& Galloway, B. 2015 , 'The moderating effect of power distance on employee responses to psychological contract breach', European Journal of Work and Organizational Psychology 24(6), 853-865. https://doi.org/10.1080/1359432X.2014.961432

Zhao, H., Wayne, S.J., Glibkowski, B.C. \& Bravo, J., 2007, 'The impact of psychological contract breach on work-related outcomes: A meta-analysis', Personnel Psychology 60(3), 647-680. https://doi.org/10.1111/j.17446570.2007.00085.x

Zhou, J. \& George, J., 2001, 'When job dissatisfaction leads to creativity: Encouragin the expression of voice', Academy of Management Journal 44(4), 682-696. https://doi.org/10.2307/3069410 